\title{
Membentuk Karakter Religius dengan Pembiasaan Perilaku Religi di Sekolah: Studi di SMA Negeri 3 Ponorogo
}

\author{
Lyna Dwi Muya Syaroh, ${ }^{1}$ Zeni Murtafiati Mizani ${ }^{2}$ \\ ${ }^{1,2}$ Institut Agama Islam Negeri (IAIN) Ponorogo \\ 1'lynasyaroh@gmail.com, ${ }^{2} z e n i @$ iainponorogo.ac.id
}

\begin{abstract}
The purpose of this research is to analyze the implementation of the habituation, constraints, and solutions encountered in implementing the habituation method to shape students' religious character. This research method uses a qualitative descriptive approach and the type of research is a case study. Data collection techniques include observation, interview and documentation. Data analysis techniques using Miles and Huberman Theory. The results of the study found that: (1) Forming religious character by habitualizing religious behavior at school is carried out through prayer activities before learning and before going home, reading short letters in juz'amma and verse verses, chanting asma'ul husna, dhuha prayer, dhuhur prayer and asar congregation, Friday prayers and Friday blessings, Friday infaq, khatmil al-Qur'an, khatib and Commemoration of Islamic Holidays (PHBI); (2) Constraints faced in shaping religious character by habitualizing religious behavior at school are influenced by two factors namely: internal factors including innate behavior and external factors including lack of maximum conditioning and support from teachers, students' educational backgrounds, different parenting , peers, social media and infrastructure; (3) The solution to overcome the constraints of religious character by habitualizing religious behavior at school is by socializing the importance of character education, discipline, reward and punishment, controlling, and adding facilities and infrastructure.
\end{abstract}

\section{Keywords: Habituation, Religious Character, School}

\begin{abstract}
Abstrak
Penelitian ini bertujuan untuk menganalisis pelaksanaan pembiasaan, kendala, dan solusi yang dihadapi dalam pelaksanaan metode pembiasaan guna membentuk karakter religius siswa. Penelitian ini menggunakan pendekatan deskriptif kualitatif dengan jenis penelitian studi kasus. Teknik pengumpulan data dalam penelitian ini menggunakan teknik observasi, wawancara dan dokumentasi. Sedangkan teknik analisis data menggunakan teori Miles dan Huberman. Hasil penelitian menemukan bahwa: (1) Membentuk karakter religius dengan pembiasaan perilaku religi di sekolah dilaksanakan melalui kegiatan berdoa sebelum belajar dan sebelum pulang, membaca surat pendek dalam juz'amma dan ayat kursi, melantunkan asma al husna, salat dhuha, salat dzuhur dan asar berjamaah, salat Jum'at dan Jum'at berkah, infaq
\end{abstract}


Jumat, khatmil al-Qur'an, khatib dan Peringatan Hari Besar Islam (PHBI); (2) Kendala yang dihadapi dalam membentuk karakter religius melalui pembiasaan perilaku religius di sekolah dipengaruhi oleh dua faktor yaitu: faktor intern meliputi perilaku bawaan dan faktor ekstern meliputi kurang maksimalnya pengondisian dan dukungan dari guru-guru, latar belakang pendidikan siswa, perbedaan pola asuh, teman sebaya, media sosial dan sarana prasarana; (3) Solusi untuk mengatasi kendala membentuk karakter religius melalui pembiasaan perilaku religius di sekolah yaitu dengan sosialisasi pentingnya pendidikan karakter, tata tertib, reward dan punishment, controlling, dan penambahan sarana dan prasarana.

Kata kunci: Karakter Religius, Pembiasaan, Sekolah

\section{Pendahuluan}

Pendidikan merupakan aspek penting dalam kehidupan yang tidak mungkin dapat dipisahkan dari kehidupan manusia. Pendidikan sebagai sebuah proses mempunyai asumsi-asumsi. Terdapat asumsi bahwa pendidikan merupakan sebuah proses yang terjadi secara alamiah dan merupakan ketidaksengajaan. Maknanya, bahwa pendidikan bukan proses yang secara terencana, teratur, terorganisir dengan menggunakan cara dan metode dengan didasarkan pada aturan yang telah ditentukan bersama. Asumsi lain menyatakan bahwa pendidikan dipercaya sebagai suatu proses yang didesain, diorganisir dan direncanakan secara sengaja berdasarkan aturan yang telah ditetapkan. ${ }^{1}$ Di Indonesia terdapat Undang-Undang yang mengatur tentang Pendidikan Nasional yakni UU SISDIKNAS No. 20 Tahun 2003.

Undang-Undang ini menyatakan bahwa pendidikan nasional memiliki fungsi dalam mengembangkan kemampuan dan membentuk watak serta peradaban bangsa yang bermartabat dalam rangka mencerdaskan kehidupan bangsa. Sedangkan tujuan dari pendidikan nasional adalah untuk mengembangkan potensi peserta didik agar menjadi manusia yang beriman dan bertakwa kepada Tuhan yang Maha Esa, berakhlak mulia, sehat, berilmu, cakap, kreatif, mandiri, dan menjadi warga negara yang demokratis serta bertanggung jawab. ${ }^{2}$

Sekolah merupakan wadah dan tempat bagi seseorang untuk mengembangkan kapasitas diri dan potensinya. Dengan diterapkannya pendidikan karakter di sekolah akan berpengaruh pada perkembangan karakter dan potensi siswa, baik dalam hal menempatkan diri, mengambil sebuah keputusan dan juga bersikap. Pendidikan karakter

\footnotetext{
${ }^{1}$ Fatchul Mu'in, Pendidikan Karakter Konstruksi Teoretik \& Praktik (Jogjakarta: Ar-Ruzz Media, 2011), 287-288.

2 Undang-Undang Republik Indonesia Nomor 20 Tahun 2003 Tentang SISDIKNAS (Bandung: Citra Umbara, 2006).
} 
dengan ciri khas agama menjadi sesuatu yang penting diterapkan di sekolah. Tujuannya adalah untuk memberi bekal kepada peserta didik dalam menghadapi dunia kerja, masyarakat dan kehidupan selanjutnya. ${ }^{3}$ Yang nyatanya dalam masyarakat dan dunia kerja sangat dipertimbangkan dan menjadi hal yang sangat penting.

Pendidikan karakter bukanlah sebuah pendidikan yang hanya sekedar menransfer pengetahuan tentang sesuatu yang salah atau benar. Tapi juga harus menransfer nilai dan menjadikan itu sebagai habituasi atau kebiasaan yang dilakukan secara berkesinambungan oleh peserta didik. Pada akhirnya, pendidikan karakter merupakan upaya menyeimbangkan kompetensi peserta didik secara utuh yang tidak hanya menekankan pada aspek kognitif, tapi juga pada aspek psikomotorik dan afektif. ${ }^{4}$

Adapun nilai karakter yang berkaitan dengan ranah hubungan manusia dengan Tuhan Yang Maha Esa adalah nilai religius. Ranah religius sangat penting untuk ditumbuhkembangkan pada peserta didik dalam rangka mengonstruk perkataan, pikiran, serta tindakan peserta didik yang diusahakan untuk selalu didasarkan pada nilai dan norma ketuhanan yang berdasarkan pada ajaran agama yang dianut. Maknanya, bahwa ajaran dan agama yang dianut pesera didik benar-benar dihayati, dipahami dan dilaksanakan pada setiap harinya. ${ }^{5}$

Konstruk character building, di dalamnya menyatakan bahwa dimensi religius sangat penting dikembangkan semaksimal mungkin. Sekolah dan orang tua memiliki peran dan tanggung jawab yang besar dalam menumbuhkembangkan karakter religius. Ajaran agama Islam mengharuskan bahwa nilai-nilai agama sudah harus ditanamkan sejak anak lahir, yang diharapkan nantinya anak memiliki karakter religius. ${ }^{6}$

Muhaimin mengungkapkan kata religius tidak mesti dan selalu berhubungan dengan agama. Keberagamaan merupakan terjemahan yang lebih dekat dan tepat dari kata religius. Karena istilah ini menilik pada "aspek yang ada dalam hati nurani terdalam” pribadi, sikap personal yang sebagian menjadi misteri bagi orang lain, karena

\footnotetext{
3 "Penerapan Pendidikan Berkarakter Di Sekolah Menengah," accessed March 16, 2020, http://www.unwaha.ac.id/artikel/penerapan-pendidikan $\quad$-berkarakter $\quad$-di-sekolah menengah/education/index.thml.

${ }^{4}$ A. Rodli Makmun, Pembentukan Karakter Berbasis Pendidikan Pesantren (Studi Di Pondok Pesantren Tradisional Dan Modern Di Kab. Ponorogo) (Ponorogo: Stain Ponorogo Press, 2014), 23.

5 Akhmad Muhaimin Azzet, Urgensi Pendidikan Karakter Di Indonesia: Revitalisasi Pendidikan Karakter Terhadap Keberhasilan Dan Kemajuan Bangsa (Jogjakarta: Ar-Ruzz Media, 2013).

${ }^{6}$ Ngainun Na'im, Character Building: Optimalisasi Peran Pendidikan Dalam Pengembangan Ilmu \& Pembentukan Krakter Bangsa (Jogjakarta: Ar-Ruzz Media, 2012), 125.
} 
menapaskan intimitas jiwa, cita rasa yang mencakup totalitas ke dalam pribadi manusia, dan bukan pada aspek yang bersifat formal. ${ }^{7}$

Problematika karakter merupakan problem yang menjadi fokus setiap bangsa, baik negara yang masih berkembang maupun negara maju. Terjadinya degradasi nilainilai karakter atau hilangnya sebuah karakter bangsa sudah barang tentu akan menjadi kelambanan perkembangan setiap bangsa, mengingat bahwa karakter setiap bangsa merupakan awal dari sebuah kemajuan bahkan menjadi sebuah pondasi dalam pembangunan. Namun ketika ditilik keadaan masyarakat Indonesia terutama para remaja saat ini berada pada posisi yang memprihatinkan. ${ }^{8}$

Hingga saat ini, pendidikan keluarga sebagai salah satu pendidikan informal sebagian besar belum banyak berkontribusi dalam memaksimalkan kompetensi dan mengembangkan karakter siswa. Padahal tujuan dan fungsi pendidikan nasional secara jelas menyatakan pendidikan di setiap jenjang dilaksanakan dengan terprogram dan sistematis untuk meraih tujuan yang terkait dengan pembentukan karakter siswa diharapkan siswa mampu memiliki moral dan etika yang baik, sopan santun, mampu bersaing, dan memiliki interaksi yang baik dengan masyarakat. ${ }^{9}$ Sudah sepatutnya keluarga dan sekolah bersinergi untuk mencapai tujuan tersebut. Sekolah sebagai lembaga formal yang penting dalam menjalankan proses pendidikan kepada peserta didiknya dengan melaksanakan pembelajaran sebagaimana mestinya. ${ }^{10}$

Krisis pendidikan karakter yang melibatkan anak-anak sekaligus peserta didik saat ini sudah sangat nyata dan mengkhawatirkan. Misalnya maraknya angka kekerasan anak-anak dan remaja, bullying, bertambahnya kasus pergaulan bebas, pornografi, pemerkosaan, perampasan hak milik orang lain, pencurian remaja, penyalahgunaan obat-obatan, telah menimbulkan masalah sosial yang belum teratasi secara tuntas hingga saat ini. ${ }^{11}$

Keadaan ini menandakan bahwa program penguatan karakter di sekolah masih menjadi sesuatu yang sangat relevan untuk mengatasi berbagai problem moral yang

\footnotetext{
${ }^{7}$ Muhaimin, Paradigma Pendidikan Islam: Upaya Mengefektifkan Pendidikan Agama Islam Di Sekolah (Bandung: PT. Remaja Rosdakarya, 2008), 288.

${ }^{8}$ Heri Cahyono, "Pendidikan Karakter: Strategi Pendidikan Nilai Dalam Membentuk Karakter Religius," Ri'ayah, no. 01 (July 2016).

${ }^{9}$ Masnur Muslich, Pendidikan Karakter Menjawab Tantangan Krisis Multidimensional (Jakarta: PT. Bumi Aksara, 2014).

${ }^{10}$ Syaiful Bahri Djamarah, Psikologi Belajar (Jakarta: Rinneka Cipta, 2002), 46.

11 Zubaedi, Desain Pendidikan Karakter: Konsepsi Dan Aplikasinya Dalam Lembaga Pendidikan (Jakarta: Kencana, 2011), 2.
} 
tampak semakin akut karena melanda berbagai lapisan generasi bangsa. ${ }^{12}$ Pendidikan agama yang ada di sekolah idealnya senantiasa eksis dan berkontribusi pada terbentuknya semangat religius yang terinternalisasi ke dalam diri peserta didik. Pendidikan berbasis religius, seharusnya memiliki peran yang bersinergi dengan suatu paradigma baru yang bisa ditawarkan dalam menyelesaikan problem sosial remaja. Kekhawatiran terkait dengan semakin tergerusnya peran agama dalam menampilkan wajah yang menyejukkan, seringkali menghadapi banyak hambatan dan tantangan, terutama dalam membentuk generasi manusia yang mengedepankan semangat persaudaraan dan solidaritas bersama tanpa memandang latar belakang dari masingmasing individu atau kelompok. ${ }^{13}$

Salah satu cara yang sangat efektif untuk diterapkan dalam pembentukan dan pembinaan karakter serta kepribadian anak adalah pembiasaan (habituation). Pembiasaan merupakan perilaku yang dengan kesadaran diri dilaksanakan secara berkesinambungan dan berulang dengan tujuan perilaku tersebut menjadi keseharian. Inti dari pembiasaan adalah pengamalan. Sesuatu yang biasa dilakukan merupakan pengamalan. Sedangkan inti dari kebiasaan yaitu pengulangan. ${ }^{14}$ Bahwasannya proses pengamalan itu tidak hanya terjadi satu ataupun dua kali tetapi berulang-ulang. Karena hal tersebut, sebagai sebuah awal dan ujung tombak pendidikan, sebuah pembiasaan adalah pilihan yang tepat. Sedari lahir seorang anak sudah selayaknya dididik dengan perbuatan dan kebiasaan baik sesuai tuntunan agama dan nilai serta norma yang ada di masyarakat. Tujuannya agar nantinya anak sudah terbentuk dan terbiasa melakukan hal baik dalam keluarga, sekolah maupun masyarakat. ${ }^{15}$

Sekolah sebagai lembaga pendidikan yang mempunyai andil penting dalam pembentukan karakter peserta didik, sudah selayaknya menciptakan budaya sekolah sehingga terwujud karakter peserta didik yang ingin dibentuk sesuai visi, misi dan tujuan pendidikan untuk membentuk manusia yang utuh. Budaya sekolah yang akan dibentuk tentunya harus didesain, dibentuk, dibangun dan dibiasakan untuk dilakukan

\footnotetext{
12 Kusairi, Bustomi Musthofa, and Susiati Alwy, "Implementasi Pengembangan Kurikulum Pendidikan Agama Islam Berbasis Pendidikan Karakter Di SMP Al Azhar Kediri," Indonesian Journal of Islamic Education Studies (IJIES) 2, no. 1 (July 13, 2019): 17-27, https://doi.org/10.33367/ijies.v2i1.818, 18.

${ }^{13}$ Mohammad Takdir Ilahi, Gagalnya Pendidikan Karakter: Analisis Dan Solusi Pengendalian Karakter Emas Anak Didik (Yogyakarta: Ar-Ruzz Media, 2014), 169.

${ }^{14}$ Heri Gunawan, Pendidikan Karakter (Bandung: Alfabeta, 2014), 93.

15 M. Ngalim Purwato, Ilmu Pendidikan Teoritis Dan Praktis (Bandung: PT. Remaja Rosdakarya, 2006), 177.
} 
oleh semua komponen di sekolah. ${ }^{16}$ Dengan demikian suatu pembiasaan yang dilakukan secara konsisten di sekolah, maka diharapkan terbentuklah suatu budaya sekolah.

Budaya sekolah penting bagi setiap jenjang pendidikan tidak terkecuali bagi siswa pada sekolah menengah atas, SMA merupakan masa yang paling menyenangkan terutama usia anak sekolah menengah atas, di mana pada usia remaja adalah usia peralihan dari remaja menuju dewasa. Maka dari itu, dalam Kurikulum 2013 (K-13) lembaga pendidikan harus mampu menanamkan, mengembangkan, dan menerapkan pendidikan karakter peserta didiknya. Satu contoh yang bisa dilaksanakan sekolah dalam membentuk karakter bagi peserta didiknya adalah memasukkan pendidikan karakter ke dalam proses pembelajaran dan bisa juga menerapkan pembiasaan di lingkungan sekolah. Sehingga karakter anak didik akan nampak pada aktivitas belajarnya di dalam kelas maupun di luar kelas.

SMA Negeri 3 Ponorogo merupakan salah satu sekolah ungggulan di Kabupaten Ponorogo. SMA Negeri 3 Ponorogo telah terakreditasi oleh Badan Akreditasi Sekolah Nasional dengan predikat A. Pembelajaran di SMA Negeri 3 Ponorogo telah menggunakan kurikulum K-13 edisi revisi. Dalam kurikulum tersebut terdapat pendidikan karakter yang harus diterapkan kepada siswa berkaitan dengan materi yang dipelajari. Sehingga semua warga sekolah harus ikut berpartisipasi dalam mengoptimalkan pelaksanaan pendidikan karakter, salah satunya dalam hal membentuk karakter religius siswa di sekolah. Sehingga nantinya akan tercipta lulusan yang menguasai bidang akademik dan non akademik serta berkarakter religius. Dalam rangka meningkatkan ketakwaan kepada Tuhan Yang Maha Esa SMA Negeri 3 Ponorogo mengimplementasikan pembiasaan. Pembiasaan ini melibatkan semua komponen yang ada di sekolah. Pembiasaan ini juga diwujudkan dalam berbagai bentuk kegiatan. Berdasarkan hal tersebut, kajian ini berupaya untuk menganalisis pelaksanaan pembiasaan dalam membentuk karakter religius siswa di SMA Negeri 3 Ponorogo.

\section{Metode}

Penelitian ini dilaksanakan di SMA Negeri 3 Ponorogo yang beralamatkan di Jl. Yos Sudarso III/I Ponorogo. Penelitian ini bertujuan untuk menganalisis pelaksanaan pembiasaan dalam membentuk karakter religius siswa. Pendekatan dalam penelitian ini menggunakan pendekatan kualitatif. Jenis penelitian ini menggunakan penelitian

\footnotetext{
16 Akhmad Muhaimin Azzet, Urgensi Pendidikan Karakter Di Indonesia: Revitalisasi Pendidikan Karakter Terhadap Keberhasilan Dan Kemajuan Bangsa (Jogjakarta: Ar-Ruzz Media, 2013), 13.
} 
lapangan (field research) dengan desai studi kasus. Teknik pengumpulan data dalam penelitian ini menggunakan teknik observasi, wawancara dan dokumentasi. Teknik analisis data menggunakan teori dari Miles dan Huberman dengan langkah-langkah mengumpulkan data, mereduksi data, display data, dan menarik kesimpulan. ${ }^{17}$

\section{Pembahasan}

\section{Proses Pembentukan Karakter Religius dengan Pembiasaan Perilaku Religi di Sekolah}

Pembiasaan merupakan proses yang membuat seseorang menjadi terbiasa akan sesuatu sehingga perilaku yang ditampilkan seakan terjadi begitu saja tanpa melalui perencanaan dan pemikiran lagi. ${ }^{18}$ Oleh karena itu, pembiasaan merupakan suatu cara yang digunakan untuk membiasakan suatu sikap dan perilaku kepada orang lain yang dilakukan secara berulang-ulang, sehingga nantinya kebiasaan tersebut akan terus tertanam dalam diri seseorang dalam menghadapi masalah kehidupannya.

Dalam menanamkan pembiasaan yang baik memang bukan hal yang mudah, seringkali membutuhkan waktu yang panjang. Akan tetapi jika suatu hal sudah menjadi kebiasaan dan bagian dari diri seseorang, maka tidak mudah pula untuk mengubahnya. Menanamkan pembiasaan yang baik bagi anak sangat penting. Seperti halnya salat lima waktu, berpuasa, suka menolong orang yang kesusahan, membantu fakir miskin dan lain sebagainya. Pembiasaan merupakan metode pendidikan yang sangat penting dalam agama Islam sangat mementingkan pendidikan dengan pembiasaan. Adanya pembiasaan tersebut memiliki tujuan agar peserta didik dapat melaksanakan ajaran agama secara istiqamah. ${ }^{19}$

Karakter religius merupakan salah satu dari nilai-nilai karakter yang ditumbuhkembangkan di sekolah. Heri Gunawan mendefinisikan karakter religius sebagai nilai karakter yang berkaitan dengan hubungan dengan tuhan yang meliputi pikiran, perkataan, dan tindakan seseorang yang diupayakan selalu berdasarkan pada nilai-nilai ketuhanan dan/atau ajaran agamanya. ${ }^{20}$ Nilai-nilai religius yang dikembangkan dalam pendidikan budaya dan karakter bangsa adalah sikap dan perilaku yang patuh dalam melaksanakan ajaran agama yang dianut, toleran terhadap

\footnotetext{
${ }^{17}$ Riyadi Santoso, Metode Penelitian Kualitatif(Surakarta: UNS Press, 2017).

${ }^{18}$ Djamarah Syaiful Bahri and Aswan Zain, Strategi Belajar Mengajar (Jakarta: PT. Rineka Cipta, 1997), 70.

${ }^{19}$ Ramayulis, Metodologi Pendidikan Agama Islam (Jakarta: Kalam Mulia, 2018).

${ }^{20}$ Gunawan, Pendidikan Karakter.
} 
pelaksanaan ibadah agama lain, dan hidup rukun dengan pemeluk agama lain. ${ }^{21}$ Sedangkan dimensi dari religiusitas menurut Muhaimin ada lima macam yakni dimensi keyakinan, dimensi praktik agama, dimensi pengalaman, dimensi pengetahuan beragama dan dimensi pengamalan dan konsekuensi. ${ }^{22}$

Pelaksanaan pembiasaan di SMA Negeri 3 Ponorogo dilaksanakan secara terprogram berdasarkan buku panduan khusus tentang Penumbuhan Budi Pekerti SMA Negeri 3 Ponorogo. Hal ini selaras dengan teori pembiasaan berdasarkan pendapat Mulyasa yang menyatakan bahwa kegiatan pembiasaan secara terprogram dapat dilaksanakan dengan perencanaan khusus dalam kurun waktu tertentu baik untuk pengembangan pribadi peserta didik secara individual, kelompok dan klasikal. ${ }^{23}$

Tujuan dari sekolah membentuk karakter siswa melalui pembiasaan adalah untuk mencetak lulusan yang berakhlak mulia, beradab dan memiliki etika yang terpuji sebagai bekal kehidupan di lingkungan keluarga, sekolah dan masyarakat. Dengan hal tersebut pihak sekolah terus berupaya secara serius dalam meningkatkan kualitas dan kuantitas pembiasaan guna membentuk karakter siswa kelas dengan cara melakukan program-program pembiasaan yang dinamis. Berbagai macam kegiatan yang disusun sekolah untuk mengembangkan karakter religius siswa adalah sebagai berikut:

1. Berdoa sebelum belajar dan sebelum pulang. Kegiatan doa yang ada di SMA Negeri 3 Ponorogo dilakukan dengan cara bersama-sama dengan menyentralkan komputer yang berada di ruang piket. Pada jam 07.00 WIB tepat guru dan peserta didik harus berada di dalam kelas. Sedangkan ketika waktu pulang sekolah kegiatan doa langsung dipimpin oleh guru mata pelajaran jam terakhir. Sedangkan untuk siswa nonmuslim, mereka berdoa sesuai dengan agama dan kepercayaannya.

2. Membaca surat pendek dalam juz'amma dan ayat kursi. Kegiatan ini dilakukan setelah melakukan doa bersama. Meskipun tidak semua guru menerapkan pembiasaan ini, akan tetapi untuk pembelajaran PAI diwajibkan. Dalam melakukan pembiasaan ini siswa membaca minimal 2 surat pendek dalam juz'amma. Kemudian dilanjutkan dengan membaca ayat kursi. Selain kegiatan membaca surat pendek dalam juz'amma. Dalam meningkatkan pembiasaan yang berbasis religius, MGMPS berupaya untuk menyusun program hafalan yang wajib dilaksanakan pada mata pelajaran PAI mulai dari kelas $\mathrm{X}$. Masing-masing siswa memiliki format

\footnotetext{
${ }^{21}$ Pupuh Fathurrohman, Pengembangan Pendidikan Karakter (Bandung: PT. Refika Aditama, 2013).

${ }_{22}^{2}$ Muhaimin, Paradigma Pendidikan Islam: Upaya Mengefektifkan Pendidikan Agama Islam Di Sekolah.

${ }^{23}$ E. Mulyasa, Manajemen Pendidikan Karakter (Jakarta: PT. Bumi Aksara, 2013), 167.
} 
lembaran yang bertuliskan nama surat dalam al-Qur'an. Dengan adanya format lembaran tersebut akan menambah motivasi siswa untuk menghafal surat dan memudahkan pelayanan untuk setor hafalan surat. Proses hafalan tersebut biasanya dilaksanakan di dalam kelas atau di masjid.

3. Melantunkan asma'ul husna. Lantunan asma'ul husna yang dibaca siswa memiliki nada yang berbeda. Masing-masing kelas memiliki lagu yang telah disepakati oleh masing-masing kelas untuk memudahkan siswa untuk membacanya.

4. Salat dhuha. Salat dhuha adalah salat yang dikerjakan pada waktu matahari sedang naik. Pada rakaat yang pertama membaca surat Asy-Syams dan pada raka'at kedua membaca surat Adl-Dhuha. ${ }^{24}$ Pelaksanaan salat dhuha di SMA Negeri 3 Ponorogo berlangsung sebelum atau sesudah jam pelajaran PAI dan ketika jam istirahat. Pelaksanaan salat dhuha dilakukan secara berjama'ah atau munfarid. Imam dalam salat dhuha adalah dari siswa itu sendiri maupun dari bapak/ibu guru.

5. Salat dhuhur dan asar berjamaah. Salat berjamaah adalah salat yang dikerjakan bersama-sama, sekurang-kurangya terdiri dari dua orang yaitu imam dan makmum. ${ }^{25}$ Dalam pelaksanaan salat berjamaah sudah diberitahukan pada seluruh siswa kelas X, XI, XII. Petugas dari perwakilan kelas harus bertanggungjawab untuk menjadi muadhin, petugas iqamah, khatib (pemberian kultum). Sedangkan untuk imamnya dari bapak guru. Agar siswa lebih disiplin dalam melaksanakan salat berjamaah, terdapat absensi untuk masing-masing kelas yang dipandu langsung oleh guru PAI.

6. Salat Jumat dan Jumat berkah. Hari jumat merupakan hari yang sangat mulia. Karena apapun amalan yang dilakukan pada hari jumat diyakini akan dilipatgandakan. Untuk itu SMA Negeri 3 Ponorogo berupaya untuk menunaikan salat jumat berjamaah di lingkungan sekolah. Seluruh warga sekolah sangat setuju dengan diadakannya salat jumat yang diselenggarakan di lingkungan sekolah. Siswa pun juga berantusias dalam mengikuti kegiatan tersebut. Salat jumat wajib bagi laki-laki dewasa yang beragama Islam, merdeka, dan tetap di dalam negeri. ${ }^{26}$ Salat jumat yang dilakukan di SMA Negeri 3 Ponorogo dikuti oleh seluruh siswa laki dan guru laki-laki serta ada beberapa dari siswa dan guru perempuan. Selain melaksanakan salat jumat, setiap jumat juga ada jumat berkah yang disediakan di

\footnotetext{
${ }^{24}$ M. Syamsuri, Penuntun Shalat Lengkap Dengan Kumpulan Doa (Surabaya: Apollo Lestari, n.d.), 79.

25 Syamsuri.

${ }^{26}$ Sulaiman Rasjid, Fiqih Islam (Bandung: Sinar Baru Algesindo, 1994).
} 
serambi masjid Nurul Iman. Makanan, minuman dan makanan ringan ditata rapi di etalase. Bisa diambil oleh siapa saja yang membutuhkan. Dana untuk kegiatan ini berasal dari para relawan dan sebagian juga berasal dari amplop infaq Jumat dari para siswa.

7. Infaq jumat. Infaq menurut istilah adalah mengeluarkan atau membelanjakan sebagian harta yang dimiliki untuk kepentingan sosial dan keagamaan dalam waktu yang tidak terbatas. Setiap jumat pagi petugas piket melakukan pembagian amplop kepada masing-masing kelas sebagai tempat terkumpulnya hasil infaq siswa. Untuk memudahkan koordinasi dengan siswa petugas bagian infaq membuat grup. Grup tersebut digunakan untuk mengontrol masing-masing kelas. Setiap perwakilan kelas dimohon untuk mengumpulkan hasil infaqnya ke ruang piket dengan menyertakan nama kelas dan nominal infaq yang telah diperoleh. Hasil infaq tersebut digunakan untuk pembangunan masjid dan untuk Jum'at berkah.

8. Khatmil al-Qur'an. Kegiatan Khatmil al-Qur'an dilaksanakan pada 1 kali dalam 1 bulan tepatnya pada jam pertama di awal bulan. Kegiatan tersebut dilaksanakan selama maksimal 1 jam (60 menit). Untuk memperlancar kegiatan masing-masing kelas dipimpin oleh guru PAI dan juga melibatkan guru lain dengan melakukan pembukaan dan penyampaian tujuan kegiatan Khatmil al-Qur'an. Salah satu tujuan kegiatan Khatmil al-Qur'an ini adalah sebagai wujud meningkatkan dan mendekatkan diri kepada Allah SWT dan juga untuk menumbuhkan karakter religius untuk semua warga sekolah tertutama pada siswa. SMA Negeri 3 Ponorogo dari kelas X hingga XII terdiri dari 30 kelas. Sehingga masing-masing kelas mendapatkan jatah 1 juz untuk membaca al-Qur'an. Masing-masing kelas ada yang membacanya secara bersama-sama atau dengan cara membagi setiap ruku' pada masing-masing anak. Setelah 1 jam berlalu kegiatan khataman ditutup dengan bacaan doa oleh bapak/ibu guru.

9. Khatib. Khatib merupakan orang yang memberikan nasihat, peringatan serta ajaran tentang agama Islam. Biasanya orang muslim menyebutnya dengan dakwah. Pembiasaan menjadi khatib di SMA Negeri 3 Ponorogo bertujuan untuk melatih keberanian siswa dalam menyampaikan gagasannya di depan orang banyak. Siswa diberikan jadwal pada kelas masing-masing yang secara bergantian untuk menjadi seorang khatib ketika selesai salat dhuhur. Seorang khatib hendaknya memiliki adab yang baik, di antaranya berpakaian yang rapi dan sopan, akhlakul 
karimah (berpribadian luhur), bertutur kata santun, jujur dan uswatun hasanah. Karakter ini pula yang berusaha dibentuk kepada peserta didik.

10. Peringatan Hari Besar Islam (PHBI). PHBI di SMA Negeri 3 Ponorogo diselenggarakan ketika peringatan hari besar Islam seperti isra miraj Nabi Muhammad SAW, pondok Ramadan, dan lain sebagainya. SMA Negeri 3 Ponorogo dalam peringatan PHBI biasanya mendatangkan seorang penceramah (mubaligh). Peringatan ini adalah bentuk upaya yang dilakukan oleh pihak sekolah guna meningkatkan rasa syukur dan mempererat hubungan silaturahmi dengan wali murid. Sedangkan pada Hari Raya Idul Fitri siswa-siswi SMA Negeri 3 Ponorogo juga bersilaturahmi ke rumah bapak dan ibu guru.

Guru Pendidikan Agama Islam (GPAI) sebagai salah satu komponen penting dalam mendukung pelaksanaan pembiasaan di sekolah memiliki beberapa cara dalam membiasakan aspek keimanan, ibadah dan akhlak. Penelitian Defi dan Yasin menemukan bahwa pembentukan karakter religius bisa dilaksanakan dalam berbagai macam kegiatan yang disesuaikan dengan masing-masing dimensi, misalnya dalam dimensi ibadah dengan menggunakan pembiasaan salat dhuhur berjama'ah. ${ }^{27}$ Di SMA Negeri 1 Ponorogo, dalam membiasakan keimanan siswa guru membiasakan siswanya untuk melakukan segala sesuatu dengan ikhlas dan senantiasa banyak berlatih di depan umum melalui kewajian menjadi khatib. Hal ini akan melatih siswa untuk semangat dalam ibadah. Dalam membiasakan ibadah guru melakukan tindakan dengan mengajak siswa untuk disiplin dan bertanggungjawab terutama dalam hal salat. Sedangkan dalam membiasakan akhlak biasanya guru memberikan tauladan kepada peserta didik. Ada beberapa manfaat yang dirasakan siswa dari pelaksanaan pembiasaan di sekolah di antaranya adalah sebagai upaya untuk mendekatkan diri kepada Allah SWT, meningkatkan kedisiplinan, menjadi pribadi yang lebih baik baik dalam hal ibadah maupun akhlak, menjadi manusia yang dewasa.

\section{Kendala yang Dihadapi dalam Pembentukan Karakter Religius dengan Pembiasaan Perilaku Religi di Sekolah}

Ada beberapa hal yang berpengaruh terhadap karakter, akhlak, moral, budi pekerti dan etika manusia. Para pakar membaginya menjadi dua faktor, faktor internal

27 Defi Sulistiyorini and Yasin Nurfalah, "Pembentukan Karakter Religius Siswa Melalui Kegiatan Dewan Jama'ah Mushola (DJM) Di SMK PGRI 2 Kota Kediri," Indonesian Journal of Islamic Education Studies (IJIES) 2, no. 1 (July 31, 2019): 40-49, https://doi.org/10.33367/ijies.v2i1.834, 40. 
dan faktor eksternal. ${ }^{28}$ Faktorn internal adalah faktor dari dalam masing-masing individu atau siswa, sedangkan faktor eksternal adalah faktor yang memengaruhi dari luar diri siswa. Secara umum, pelaksanaan pembiasaan guna membentuk karakter religius siswa di SMA Negeri 3 Ponorogo memiliki beberapa kendala, sebagai berikut:

1. Perilaku Bawaan/Naluriah

Perilaku bawaan maksudnya adalah fitrah karakter anak yang dibawa sedari lahir. Dengan perbedaan karakter ini, menyebabkan respon yang berbeda-beda terhadap hal yang telah dilakukan oleh siswa berdasarkan pengalaman belajar di lingkungan sekolah. Termasuk dalam menerapkan pembiasaan-pembiasaan yang ada di sekolah. Dari karakter yang berbeda ini tentunya memerlukan treatment yang berbeda pula untuk masing-masing anak. Terdapat sebagian anak didik yang dapat dengan mudah mengubah sikap dan perilaku dengan hanya teguran saja, akan tetapi ada yang harus dengan tindakan tegas. Hal ini pulalah yang terjadi dalam pembiasaaan yang dikembangkan di SMA Negeri 3 Ponorogo.

2. Pola Asuh yang Berbeda

Pola asuh merupakan pola interaksi antara orang tua dengan anak yang mencakup pemenuhan kebutuhan fisik, psikologis, dan sosialisasi norma-norma yang berlaku di masyarakat agar anak dapat hidup selaras dengan lingkungannya. ${ }^{29}$ Jadi pola asuh juga dapat diungkapkan sebagai pola interaksi antara anak dengan orang tua yang di dalamnya terdapat proses pendidikan di lingkungan keluarga. Jika orang tua menanamkan pola asuh yang baik tentu perkembangan anak dan karakter anak akan terbentuk dengan baik pula.

Pola asuh telah menjadi satu dari beberapa faktor yang berpengaruh terhadap karakter anak dalam aktivitas hidupnya. Sejak kecil anak diasuh oleh kedua orang tua dengan pendidikan yang berbeda-beda. Selama saya melakukan pengamatan aktivitas siswa, mereka melakukan segala aktivitas di lingkungan sekolah tentu punya ciri khas yang berbeda-beda. Misalnya saja ada siswa yang diperitah gurunya untuk menjadi khatib, ada anak yang siap bersedia dan ada juga anak yang tidak bersedia karena merasa kurang percaya diri. Dari hal tersebut

\footnotetext{
${ }^{28}$ Gunawan, Pendidikan Karakter Konsep Dan Implementasi.

29 Jalaluddin and Abdullah Idi, Filsafat Pendidikan Manusia, Filsafat, Dan Pendidikan (Depok: PT. Raja Grafindo Persada, 2013), 215.
} 
dalam dipahami bahwa pola asuh yang diberikan orang tua akan berpengaruh juga terhadap kualitas anak.

3. Kurang Maksimalnya Pengondisian dan Dukungan dari Tenaga Pendidik

Pengondisian berkaitan dengan upaya sekolah untuk menata lingkungan fisik maupun nonfisik demi terciptanya suasana yang mendukung terlaksananya pendidikan karakter. $^{30}$ Salah satu yang menyebabkan kurangnya pengondisian dalam menerapkan pembiasaan dalam membetuk karakter religius siswa di SMA Negeri 3 Ponorogo karena guru PAI yang ada di SMA Negeri 3 Ponorogo hanya berjumlah 4 orang. Sedangkan jumlah siswa yang ada di SMA Negeri 3 Ponorogo adalah 1.053 siswa. Selain jumlah guru PAI yang terbatas, juga dipengaruhi oleh kurang maksimalnya dukungan dari guru-guru mata pelajaran lain, masih terdapat anggapan bahwa pembiasaan religius menjadi kewajiban dari kepada guru PAI saja.

4. Latar Belakang Pendidikan Siswa

Pendidik bukan satu-satunya faktor penentu keberhasilan dan mutu pendidikan. Akan tetapi faktor potensi anak didik juga memiliki andil penting. Salah satu hal yang berkaitan dengan potensi kebaikan peserta didik adalah latar belakang pendidikan. Pembelajaran yang efektif adalah ketika guru mampu mengidentifikasi dan memahami beragam karakteristik peserta didik, serta mampu melaksanakan pembelajaran dengan tanpa mengenyampingkan berbagai macam karakteristik peserta didik tersebut. ${ }^{31}$

Pendidikan yang diperoleh siswa di SMA Negeri 3 Ponorogo tentu sangat beraneka ragam. Selain itu, masing-masing siswa memiliki pengalaman belajar sebelumnya yang berbeda. Dengan latar belakang yang tidak sama, maka tingkat pengetahuan keagamaan dan keimanan siswa pun juga tidak sama.

5. Teman Sebaya

Teman sebaya adalah seseorang yang mempunyai usia, status dan pola pikir yang hampir sama. Teman sebaya mempunyai kontribusi bagi siswa di mana pun mereka berada, demikian juga di lingkungan sekolah. ${ }^{32}$

30 Raudati Muliani, "Penerapan Pendidikan Karakter Di SDN 06 Pangkalan Kecamatan Koto Baru Kabupaten Lima Puluh Provinsi Sumatera Barat," Lentera 5 (Oktober 2014), 89-90.

31 Agung Setiyawan, "Problematika Keragaman Latar Belakang Pendidikan Mahasiswa Dan Kebijakan Program Pembelajaran Bahasa Arab," Arabiyat: Jurnal Dalam Pendidikan Bahasa Arab Dan Kebahasaaraban 5, no. 2 (Desember 2018).

32 Yusuf Kuriawan and Ajat Sudarajat, "Peran Teman Sebaya Dalam Pembentukan Karakter Siswa Madrasah Tsanawiyah,” Jurnal Ilmu-Ilmu Sosial 15 (2018), 154. 
Di lingkungan SMA Negeri 3 Ponorogo, teman sebaya menjadi salah satu faktor penting dalam mendukung ataupun menghambat dalam membangun religiusitas siswa. Ketika sesama teman memiliki kebiasaan untuk saling mengingatkan mengenai aturan di sekolah, maka akan mendukung proses internalisasi karakter religius. Seperti halnya mereka akan menegur teman ketika mereka tidak mau melakukan pembiasaan yang ada di sekolah. Tentu akan sangat mendukung terciptanya karakter tersebut, begitu juga sebaliknya.

6. Media Sosial

Media dan sosial merupakan dua kata yang membentuk istilah media sosial. Media dapat diartikan sebagai alat komunikasi. Sedangkan kata sosial dimaknai sebagai sebuah kenyataan sosial yang memiliki makna bahwa masingmasing individu melakukan tindakan yang memiliki kontribusi terhadap masyarakat. Kalimat di depan menjelaskan bahwa semua perangkat lunak dan media merupakan "sosial" atau bisa dipahami bahwasannya keduanya adalah hasil dari proses sosial. Dengan demikian media sosial merupakan alat komunikasi yang digunakan oleh pengguna dalam proses sosial. ${ }^{33}$

Perkembangan media sosial, hal ini tentu akan menimbulkan hal yang positif dan negatif terhadap karakter siswa di SMA Negeri 3 Ponorogo. Hal positifnya siswa akan banyak belajar melalui media sosial yang dimiliki masingmasing siswa. Walaupun begitu, jika siswa tidak memiliki kontrol diri dan kebijakan diri dalam menggali segala informasi yang ada melalui media sosial, maka siswa nantinya akan terjerumus ke dalam hal yang tidak dïnginkan. Siswa tentu akan meniru segala sesuatu yang ada di media sosial dan menyebarluaskan segala informasi tanpa mengetahui bukti kebenarannya dan sumber yang jelas.

7. Sarana dan Prasarana

Aspek penting dalam menjalankan pendidikan yang berkualitas salah satunya adalah fasilitas pendidikan. Fasilitas adalah sarana dan prasarana yang harus disediakan dan diberikan dengan tujuan memberikan kelancaran pada kegiatan pendidikan yang dilaksanakan di sekolah. ${ }^{34}$ Sarana pendidikan merupakan peralatan dan perlengkapan yang dimanfaatkan untuk menunjang proses pendidikan

\footnotetext{
${ }^{33}$ Mulawarman and Aldila Dyas Nurfitri, "Perilaku Pengguna Media Sosial Beserta Implikasinya Ditinjau Dari Perspektif Psikologi Sosial Terapan,” Buletin Psikologi 25 (2017).

${ }^{34}$ Popi Sopiatin, Manajemen Belajar Berbasis Kepuasan Siswa (Bogor: Ghalia Indonesia, 2010).
} 
secara langsung. Sedangkan prasarana pendidikan merupakan fasilitas penunjang berjalannya proses pendidikan secara tidak langsung.

Sarana dan prasarana yang dimiliki SMA Negeri 3 Ponorogo sebagai perlengkapan guna melaksanakan kegiatan pembiasaan karakter religius bisa dikategorikan memadai. Akan tetapi masih perlu adanya pembenahan dan penambahan pada beberapa hal. Salah satunya adalah perbaikan dan penambahan tepat wudhu dan volume air yang digunakan untuk wudhu. Kebutuhan ini utamanya saat musim kemarau yang debit air turun. Walaupun sebenarnya SMA Negeri 3 Ponorogo sebenarnya masjid yang digunakan sebagai tempat ibadah sudah dibangun dengan megah dan luas, akan tetapi kurang memadai dengan pertambahan jumlah siswa setiap tahunnya.

\section{Solusi untuk Mengatasi Kendala Pembentukan Karakter Religius dengan Pembiasaan Perilaku Religi di Sekolah}

1. Sosialisasi Pentingnya Pendidikan Karakter

Sosialisasi merupakan suatu proses di mana seseorang diharuskan untuk mampu menyesuaikan dan menempatkan diri sesuai dengan pola perilaku individu yang ada di sekitar individu tersebut. Penyesuaian ini mencakup beberapa aspek yang terdiri dari kebiasaan, sikap, ide-ide, pola hubungan sosial, nilai dan tingkah laku. ${ }^{35}$ Tahap ini merupakan pondasi yang dapat menjadi dasar pembentukan diri pribadi anak. Pada lingkungan sekolah, peserta didik pasti akan berinteraksi dengan pola-pola perilaku yang bermacam-macam dan unik. Hal ini disebabkan karena perbedaan bahasa, suku, agama dan budaya yang berbeda.

Sekolah menyadari pentingnya proses sosialisasi pendidikan karakter antara guru dan siswa. Dengan adannya sosialisasi akan memudahkan proses yang ingin dicapai terkait dengan pembentukan karakter religius dan juga berbagai karakter yang akan dibentuk oleh sekolah sesuai tujuan sekolah. Proses sosialisasi dilakukan secara langsung dan terjadwal yang ditujukan bagi keseluruhan komponen sekolah yaitu mulai dari kepala sekolah, guru dan siswa.

2. Tata Tertib

Tata tertib adalah serangkaian aturan yang harus ditaati oleh seluruh komponen sekolah. Tata tertib sekolah berbentuk peraturan tertulis yang dibuat sekolah dan

\footnotetext{
35 Anwar, "Paradigma Sosialisasi Dan Kontribusinya Terhadap Pengembangan Jiwa Beragama Anak,"
} Jurnal Al-Maiyyah, no. 11 (June 2018). 
wajib ditaati oleh seluruh warga sekolah guna melaksanakan tata tertib yang ada. Tata tertib di sekolah dibentuk untuk mengatur serangkaian kegiatan sekolah sehingga akan tercipta suasana yang tertib dan teratur. Adanya tata tertib di SMA Negeri 3 Ponorogo berfungsi sebagai kontrol perilaku siswa, pedoman perilaku siswa, dan lain sebagainya. Tata tertib ini dilaksanakan dan dievaluasi oleh kepala sekolah dan guru. Untuk melihat ketercapaian, kendala dan hambatan di lapangan, untuk selanjutnya apakah perlu diadakan pembaharuan atau tidak sesuai karakteristik dan perkembangan karakter siswa.

\section{Reward dan Punishment.}

Ngalim Purwanto mendefinisikan reward (ganjaran) sebagai alat yang dapat digunakan untuk mendidik anak agar mereka merasa senang karena apa yang telah dilakukan memperoleh penghargaan. ${ }^{36}$ Reward merupakan suatu penghargaan atau apresiasi yang telah diberikan kepada seseorang dalam bentuk materi atau ucapan. Reward yang diberikan di SMA Negeri 3 Ponorogo dalam pelaksananaan pembiasaan karakter religius siswa tidak harus berupa barang akan tetapi bisa juga dengan kata-kata pujian. Misalnya ketika siswa mendapatkan nilai yang memuaskan, datang ke sekolah tepat waktu, menjadi muadzin, dan menjadi kultum salat dhuhur, membantu bapak dan ibu guru dan beberapa tindakan lainnya. Salah satu reward yang diberikan berupa kata-kata kepada siswa adalah dengan ucapan terima kasih. Selain itu seorang guru tidak bosan-bosan juga untuk terus mengajak siswanya untuk melaksanakan pembiasaan di sekolah.

Sedangkan punishment (hukuman) adalah penderitaan yang diberikan atau ditimbulkan dengan sengaja oleh seseorang (orang tua, guru, dan sebagainya) sesudah terjadi suatu pelanggaran, kejahatan atau kesalahan. ${ }^{37}$ Punishment merupakan cara yang dilakukan untuk memberikan hukuman atau peringatan agar tingkah laku seseorang bisa sesuai dengan peraturan yang berlaku. Masing-masing guru memiliki cara sendiri dalam menerapkan punishment kepada peserta didiknya. Salah satu hal yang dilakukan oleh guru PAI ketika yang mengetahui anak didiknya tidak mengikuti pembiasaan sekolah seperti salat jumat, salat dhuha, salat dhuhur berjamaah, dan pembiasaan lainnya. Guru tersebut memberikan punishment berupa teguran, peringatan dan hukuman kepada siswa. Hukuman yang diberikan tidak berupa fisik (seperti menendang, memukul dan lain sebagainya). Ketika siswa

\footnotetext{
${ }^{36}$ Purwato, Ilmu Pendidikan Teoritis Dan Praktis.

${ }^{37}$ Purwato, 186.
} 
melakukan kesalahan yang sama lebih dari tiga kali, biasanya guru meminta siswa untuk membuat surat pernyataan yang ditandatangani oleh wali kelas, BK, dan orang tua. Hal tersebut dilihat dari tindakan apa yang sudah dilakukannya. Dengan adanya punishment tersebut harapannya adalah siswa bisa tertib menjalankan aktivitas pembiasaan dan kegiatan belajar lainnya di sekolah sesuai tata tertib yang ada.

\section{Controlling}

Controlling dapat diartikan sebagai salah satu kegiatan untuk mengetahui realisasi perilaku personal dalam organisasi pendidikan dan apakah tingkat pencapaian sesuai dengan yang dikehendaki, kemudian dari hasil pengawasan terseut apakah dilakukan perbaikan. ${ }^{38}$ Controlling juga merupakan proses pengawasan dan pengendalian yang dilakukan untuk memastikan seluruh kegiatan yang sudah terprogram dapat dijalankan sesuai dengan target dan tujuan yang diharapkan. Dengan adanya proses pengendalian akan tercipta keselarasan dan ketertiban. Proses controlling atau pengawasan yang dilakukan oleh SMA Negeri 3 Ponorogo dalam menerapkan pembiasaan karakter religius siswa dengan cara bekerjasama dengan bapak ibu guru, wali kelas, BK dan wali murid. Hal tersebut dilakukan guna mengawasi atau mengontrol setiap aktivitas yang lakukan siswa di lingkungan sekolah atau keluarga. Dengan sistem controlling atau pengawasan dapat menjadi bahan evaluasi agar pelaksanakan program yang dijalankan bisa lebih baik lagi.

5. Penambahan Sarana dan Prasarana

Fasilitas merupakan segala sesuatu yang dapat membantu dan memudahkan seluruh kegiatan atau aktivitas pendidikan. Fasilitas di SMA Negeri 3 Ponorogo tergolong lengkap. Untuk mengatasi kendala pada saat musim kemarau panjang yaitu berkaitan dengan berkurangnya air yang digunakan untuk wudhu. Maka sekolah mengupayakan untuk mengatasi hal tersebut dengan menambahkan fasilitas wudhu termasuk sumber air dan membuat tempat wudhu di sekitar masjid. Fasilitas tersebut terdiri dari tempat wudhu darurat untuk laki-laki di sebelah selatan masjid dan tempat wudhu perempuan di sebelah utara masjid. Karena pada saat ini masih sering dijumpai tempat wudhu darurat tersebut masih tercampur antara laki-laki dan perempuan.

\footnotetext{
${ }^{38}$ Syaiful Sagala, Administrasi Pendidikan Kontemporer (Bandung: Alfabeta, 2013).
} 


\section{Penutup}

Berdasarkan hasil penelitian tentang pelaksanaan pembiasaan dalam membentuk karakter religius siswa di SMA Negeri 3 Ponorogo di atas, peneliti dapat menyimpulkan bahwa pelaksanaan pembiasaan dalam membentuk karakter religius siswa di SMA Negeri 3 Ponorogo dilaksanakan secara terprogram berdasarkan buku panduan khusus tentanh Penumbuhan Budi Pekerti SMA Negeri 3 Ponorogo yaitu: (1) Berdoa sebelum belajar dan sebelum pulang; (2) Membaca surat pendek dalam juz'amma dan ayat kursi; (3) Melantunkan asma al husna; (4) Salat dhuha; (5) Salat dhuhur dan asar berjamaah; (6) Salat Jumat dan Jumat berkah; (7) Infaq Jumat; (8) Khataman al-Qur'an; (9) Khatib; (10) Peringatan Hari Besar Islam (PHBI). Kendala yang dihadapi dalam mengimplementasikan pembiasaan dalam membentuk karakter religius siswa di SMA Negeri 3 Ponorogo yaitu; (1). Faktor internal meliputi perilaku bawaan; (2) Faktor ekstern meliputi kurang maksimalnya pengondisian dan dukungan dari guru-guru, latar belakang pendidikan siswa, pola asuh orang tua, teman sebaya, media sosial dan sarana prasarana. Solusi untuk mengatasi kendala pelaksanaan pembiasaan dalam membentuk karakter religius siswa di SMA Negeri 3 Ponorogo yaitu: (1) sosialisasi pentingnya pendidikan karakter; (2) tata tertib; (3) reward dan punishment (4) controlling; (5) penambahan sarana prasarana.

\section{Daftar Rujukan}

Anwar. "Paradigma Sosialisasi Dan Kontribusinya Terhadap Pengembangan Jiwa Beragama Anak.” Jurnal Al-Maiyyah, no. 11 (June 2018).

Azzet, Akhmad Muhaimin. Urgensi Pendidikan Karakter Di Indonesia: Revitalisasi Pendidikan Karakter Terhadap Keberhasilan Dan Kemajuan Bangsa. Jogjakarta: Ar-Ruzz Media, 2013.

Cahyono, Heri. "Pendidikan Karakter: Strategi Pendidikan Nilai Dalam Membentuk Karakter Religius." Ri'ayah, no. 01 (July 2016).

Djamarah, Syaiful Bahri. Psikologi Belajar. Jakarta: Rinneka Cipta, 2002.

E. Mulyasa. Manajemen Pendidikan Karakter. Jakarta: PT. Bumi Aksara, 2013.

Fathurrohman, Pupuh. Pengembangan Pendidikan Karakter. Bandung: PT. Refika Aditama, 2013.

Gunawan, Heri. Pendidikan Karakter. Bandung: Alfabeta, 2014.

Pendidikan Karakter Konsep Dan Implementasi. Bandung: Alfabeta, 2014.

Ilahi, Mohammad Takdir. Gagalnya Pendidikan Karakter: Analisis Dan Solusi Pengendalian Karakter Emas Anak Didik. Yogyakarta: Ar-Ruzz Media, 2014. 
Jalaluddin, and Abdullah Idi. Filsafat Pendidikan Manusia, Filsafat, Dan Pendidikan. Depok: PT. Raja Grafindo Persada, 2013.

Kuriawan, Yusuf, and Ajat Sudarajat. "Peran Teman Sebaya Dalam Pembentukan Karakter Siswa Madrasah Tsanawiyah.” Jurnal Ilmu-Ilmu Sosial 15 (2018).

Kusairi, Bustomi Musthofa, and Susiati Alwy. "Implementasi Pengembangan Kurikulum Pendidikan Agama Islam Berbasis Pendidikan Karakter Di SMP Al Azhar Kediri." Indonesian Journal of Islamic Education Studies (IJIES) 2, no. 1 (July 13, 2019): 17-27. https://doi.org/10.33367/ijies.v2i1.818.

Makmun, A. Rodli. Pembentukan Karakter Berbasis Pendidikan Pesantren (Studi Di Pondok Pesantren Tradisional Dan Modern Di Kab. Ponorogo). Ponorogo: Stain Ponorogo Press, 2014.

Moleong, Lexy. J. Metodologi Penelitian Kualitatif. Bandung: PT Remaja Rosdakarya, 2000.

Muhaimin. Paradigma Pendidikan Islam: Upaya Mengefektifkan Pendidikan Agama Islam Di Sekolah. Bandung: PT. Remaja Rosdakarya, 2008.

Mu'in, Fatchul. Pendidikan Karakter Konstruksi Teoretik \& Praktik. Jogjakarta: ArRuzz Media, 2011.

Mulawarman, and Aldila Dyas Nurfitri. "Perilaku Pengguna Media Sosial Beserta Implikasinya Ditinjau Dari Perspektif Psikologi Sosial Terapan.” Buletin Psikologi 25 (2017).

Muliani, Raudati. "Penerapan Pendidikan Karakter Di SDN 06 Pangkalan Kecamatan Koto Baru Kabupaten Lima Puluh Provinsi Sumatera Barat." Lentera 5 (Oktober 2014).

Muslich, Masnur. Pendidikan Karakter Menjawab Tantangan Krisis Multidimensional. Jakarta: PT. Bumi Aksara, 2014.

Na'im, Ngainun. Character Building: Optimalisasi Peran Pendidikan Dalam Pengembangan Ilmu \& Pembentukan Krakter Bangsa. Jogjakarta: Ar-Ruzz Media, 2012.

“Penerapan Pendidikan Berkarakter Di Sekolah Menengah.” Accessed March 16, 2020. http://www.unwaha.ac.id/artikel/penerapan-pendidikan -berkarakter -di-sekolah menengah/ed ucation/index.thml.

Purwato, M. Ngalim. Ilmu Pendidikan Teoritis Dan Praktis. Bandung: PT. Remaja Rosdakarya, 2006.

Ramayulis. Metodologi Pendidikan Agama Islam. Jakarta: Kalam Mulia, 2018.

Rasjid, Sulaiman. Fiqih Islam. Bandung: Sinar Baru Algesindo, 1994.

Sagala, Syaiful. Administrasi Pendidikan Kontemporer. Bandung: Alfabeta, 2013.

Santoso, Riyadi. Metode Penelitian Kualitatif. Surakarta: UNS Press, 2017.

Setiyawan, Agung. "Problematika Keragaman Latar Belakang Pendidikan Mahasiswa Dan Kebijakan Program Pembelajaran Bahasa Arab." Arabiyat: Jurnal Dalam Pendidikan Bahasa Arab Dan Kebahasaaraban 5, no. 2 (Desember 2018).

Sopiatin, Popi. Manajemen Belajar Berbasis Kepuasan Siswa. Bogor: Ghalia Indonesia, 2010. 
Sulistiyorini, Defi, and Yasin Nurfalah. "Pembentukan Karakter Religius Siswa Melalui Kegiatan Dewan Jama'ah Mushola (DJM) Di SMK PGRI 2 Kota Kediri." Indonesian Journal of Islamic Education Studies (IJIES) 2, no. 1 (July 31, 2019): 40-49. https://doi.org/10.33367/ijies.v2i1.834.

Syaiful Bahri, Djamarah, and Aswan Zain. Strategi Belajar Mengajar. Jakarta: PT. Rineka Cipta, 1997.

Syamsuri, M. Penuntun Salat Lengkap Dengan Kumpulan Doa. Surabaya: Apollo Lestari, n.d.

Undang-Undang Republik Indonesia Nomor 20 Tahun 2003 Tentang SISDIKNAS. Bandung: Citra Umbara, 2006.

Zubaedi. Desain Pendidikan Karakter: Konsepsi Dan Aplikasinya Dalam Lembaga Pendidikan. Jakarta: Kencana, 2011. 